\title{
Shadow Banking, Bank Liquidity and Monetary Policy Shocks in Emerging Economies: A Panel VAR Analysis
}

\author{
Sheunesu Zhou \\ University of Zululand, South Africa \\ ZhouS@unizulu.ac.za, sheuedu@gmail.com
}

\begin{abstract}
The study provides an analysis of the relationships between shadow banking, bank liquidity and monetary policy rate in emerging economies. It is aimed at broadening knowledge on the effects of shadow banking on monetary policy transmission. Furthermore, the study seeks to analyse the impact of changes in bank liquidity on the growth of the shadow banking sector. We employ panel VAR technique to analyse the dynamics of monetary policy, shadow banking and bank liquidity using data for 15 emerging economy countries. We find that a contractionary monetary policy shock results in a decrease in shadow banking and a decrease in bank liquidity. We also find that a positive shock in bank liquidity increases shadow bank growth and a positive shock in shadow banking also increases bank liquidity. The results point to complementarity between shadow banking and bank liquidity; close interconnectedness between the two sectors; and the dominance of risk-taking in emerging economies. We suggest coordination between monetary policy and prudential regulation to improve the potency of monetary policy.
\end{abstract}

Keywords: Monetary policy, bank liquidity, shadow banking, panel VAR.

\section{Introduction}

The shadow banking ${ }^{1}$ sector accelerated growth in advanced economies in the period prior to the financial crisis and its negative role in propagating systemic risk is well documented (Adrian and Ashcraft, 2016, FSB, 2017). Research on the economic benefits and costs of this sector have however been limited by its opaque nature and hence lack of data that accompanies such opacity. Whilst there is no debate on the existence of this sector and the role played by shadow banks, it is not clear as yet how its growth impacts monetary policy transmission. However, with the continued growth of shadow banking assets in both advanced and emerging economies, it is ideal to analyse the possible impact this has on monetary policy transmission to proffer new ideas on how to improve monetary policy frameworks in different countries. The purpose of our paper therefore, is to empirically analyse the linkages between shadow banking and monetary policy within the context of emerging economies. Contributions made in this direction range from studies that analyse the association between price stability and financial stability (Smets, 2014, Hellwig, 2015), papers on effectiveness of monetary policy that accounts for shadow bank activities (Ge, 2011, Verona et al., 2013) and also studies that directly investigate linkages between shadow banking and monetary policy (Chen et al., 2017, Nelson et al., 2018, Verona et al., 2013, Xiang and Qianglong, 2014).

In addition, the role of shadow banks in risk taking has also been investigated (Zhou and Tewari, 2019b). The risk taking channel of monetary policy describes the response of economic agents to changes in the policy rate by increasing or decreasing their uptake of risky assets (Borio and Zhu, 2012). A monetary policy shock is deemed to impact financial agents' risk taking in at least two ways (Gambacorta, 2009). Firstly, a negative shock in the interest rate induces agents to substitute low interest government bonds with high risk, high return assets. Secondly, variations in monetary policy rate impact asset valuation and risk metrics. For instance, lowering the nominal interest rate reduces volatility estimate, hence impacts risk metrics favourably, consequently leading to increase in risk appetite of economic agents. Others have also argued that increased risk uptake by financial agents in the shadow banking sector lead to financial sector fragility and slows down business cycle recovery (Moreira and Savov, 2017, Adrian and Ashcraft, 2016). The linkages between monetary policy and the non-bank financial sector complicate the assumed dichotomy between price stability and financial stability. Smets (2014) show that the decision on how to relate monetary policy

\footnotetext{
${ }^{1}$ Shadow banking is defined by the Financial Stability Board (FSB, 2017) as, "credit intermediation involving entities and activities (fully or partly) outside of the regular banking system"
} 
and financial stability depends on three things: the efficacy of macro-prudential regulations, significance of risk taking channel of monetary policy and extent of financial dominance².

Monetary policy is linked to non-bank financial sector through two channels, the interest rate and liquidity. Firstly, changes in the interest rate influence financial market participants' risk taking (Gambacorta, 2009). The second link is provided by the substitutability between bank liquidity and wholesale market liquidity, so that in times of monetary contraction, non-bank financial firms provides liquid liabilities to the banking sector (Aftab and Varotto, 2017). Whilst this is contrary to Adrian and Shin (2009)'s observation that liquidity is only of a global nature, it is intuitive that banks source for liquid assets from wholesale markets during periods of monetary contraction, thereby maintaining their operations and weakening monetary policy. This study aims to analyse the response of shadow banking and bank liquidity to an innovation to the monetary policy rate in a panel VAR framework. Two closely related works to ours are Nelson et al. (2018) and Chen et al. (2017) who relate shadow banking to monetary policy in the US and China respectively. We extend this literature by considering a panel of emerging economies in a panel VAR framework. If the direct impact of the policy rate is dominant than via bank liquidity, the implication could be that the risk-taking channel's impact on shadow banking offsets the effect of variations in bank deposits.

Our theoretical contribution stems from investigating the channels that link monetary policy to shadow banking. Therefore, the two propositions being tested are: firstly, a positive shock in the interest rate will increase bank risk, attenuate risk taking and reduce shadow banking activities, and eventually decrease shadow bank growth. Secondly, a positive shock in the policy rate should result in a decrease in bank deposits/bank liquidity, however banks maintain their credit creation activities using shadow bank liabilities, which in turn increases shadow banking. Our results show that shadow banking responds negatively to an innovation in the policy rate and responds positively to a positive shock in bank liquidity. We therefore do not find evidence of substitutability between bank liabilities and shadow bank liabilities. Instead the study findings suggest the presence of risk taking in the non-bank financial sector, which result in expansion of shadow banking during when interest rates are low and contraction of shadow banking in times of high interest rates in emerging economies. Our paper is organised as follows: in Section 2, literature on shadow banking and monetary policy transmission is reviewed. Section 3 outlines the methodology used in the study, and the results of the analysis are presented in section 4. Section 5 provides conclusions and recommendations.

\section{Literature Review}

Theoretically, the study is positioned within the body of literature that links monetary policy to financial sector disturbances (Smets, 2014, Knoop, 2008). Standard models of monetary policy such as the New Keynesian Dynamic Stochastic General Equilibrium (DSGE) Models have evolved to account for macroprudential policy in addition to monetary policy (Galí, 2015, Chen and Columba, 2016). In addition, theories of financial frictions have been used to explain the relationship between monetary policy and the financial sector within the DSGE framework (Bernanke et al., 1999). However, whilst these succinctly show the balance sheet channels of monetary policy transmission, they do little in explaining instability originating from the financial sector. To complement this deficiency, several studies have attempted to augment these models with a banking sector (Gertler and Karadi, 2011, Mazelis, 2014, Simpasa et al., 2014). More so, others have further included a shadow banking sector in their analyses (Verona et al., 2013, Xiang and Qianglong, 2014). We add to this body of literature by empirically estimating the relationship between monetary policy, bank liquidity and shadow banking within a panel VAR framework.

Empirical studies surveyed include those focusing on the linkages between monetary policy and the financial sector through both the risk taking channel and the non-bank financial sector (Nelson et al., 2018, Chen et al., 2017, Borio and Zhu, 2012, Zhou and Tewari, 2019b, Xiao, 2018). Xiao (2018)'s work documents a shadow banking channel of monetary policy for the US. Their study is based on two assumptions, the first being that shadow banks offer inferior services and the other being depositors with different yield sensitivity. They

2 It refers to, "the risk that financial stability considerations undermine the credibility of the central bank's price stability mandate" Smets (2014) 
demonstrate that about 35\% of drop in bank deposits during monetary contraction is off-set by an increase in shadow bank deposits. Shadow banks offer high interest rates and therefore depositors switch from formal banks to shadow banks seeking high yields. Haisen and Yazdifar (2015) undertake a similar study for China using SVAR model and OLS regression. They conclude that an increase in shadow banking has the effect of increasing money supply and the price level. They support Xiao (2018)'s findings that monetary policy becomes less potent in the presence of shadow banking.

Nelson et al. (2018) also employ the Bayesian VAR approach and simulate the effect of monetary policy changes on both assets of formal banks and shadow banks. They argue for a pro-cyclical response of commercial bank assets to a shock in monetary policy and a contra cyclical response of shadow bank asset growth to the same shock. In addition, their study builds a DSGE model with shadow banks, which is able to explain theoretically their findings from the Bayesian VAR. Their results are further buttressed by Chen et al. (2017) who investigate the association between shadow banking and monetary policy in China. The study employs both descriptive analysis and panel VAR model. They find monetary policy contraction to lower bank loans but increases high risk non-loan assets. Evidence from both analyses demonstrates that contractionary monetary policy positively impacts shadow banking. Mazelis (2014) employs a DSGE model and find contractionary monetary policy to decrease bank loans whilst at the same time it increases shadow bank loans. In their model, the presence of shadow banks dampens the power of monetary policy as represented by a Taylor rule. Mazelis (2014) also find that the presence of shadow banks increase the elasticity of other variables in their model to a shock in monetary policy. Using corporate loan pricing policies, Paligorova and Santos (2017) investigates the risk taking channel for the US. Their study shows that monetary policy stance has an effect on loan spreads. They find high risk banks to respond to monetary tightening by increasing their yield spreads. On the contrary, in periods of monetary easing, high risk banks reduce spreads, limiting the full impact of monetary policy changes.

In another study, Aftab and Varotto (2017) use money market funds (MMFs) in analysing liquidity regulations' impact on shadow banking. They find that new regulations have increased the resilience of MMFs. In a related study, Loutskina (2011) investigates the impact of bank securitisations on sustainability of lending. Their studies construct a new index of bank loan liquidity and employ regression analysis to analyse liquidity of US banks. Their findings show that securitisation increases the lending ability of banks, in fact liquid assets provided through securitisation act as substitutes to bank deposits. Further, securitisations are found to increase bank liquidity and reduce effectiveness of monetary policy. In related studies, the relationship between monetary policy and bank regulation has been investigated by De Moraes et al. (2016). Their study analyses the response of banks to monetary policy changes by focusing on capital requirements and the risk taking channel. They conclude that banks respond to monetary policy changes through altering loan loss provisions and their capital adequacy ratio. Their study challenges the separate use of prudential regulation and monetary policy. They point to an integrated approach, which can ensure that the conduct on macroeconomic policy does not, influence prudential oversight negatively. De Moraes et al. (2016) show that monetary policy impacts micro-prudential supervision, which calls for close coordination between the different policies.

Bruno and Shin (2014) argue for a cross border risk taking channel for the US. The study employs a recursive VAR in which implied volatility, the real interest rate, leverage and real effective exchange rate are endogenous variables. According to Bruno and Shin (2014), banks are a vital element in the transmission mechanism and their cross border operations are elastic to movements in the policy stance. The finding is important as it confirms evidence on the susceptibility of shadow bank liabilities to sudden withdrawals (Moreira and Savov, 2017). They are therefore, more vulnerable to sudden withdrawals in the face of economic or financial instability, increasing the instability in the process. In another study, De Nicolò et al. (2010) employ ordinary least squares (OLS) procedure and scatter diagrams to demonstrate a negative association between the ratio of risk weighted assets of banks to capital and the US policy rate. They establish a negative association between the two variables signifying the presence of a risk taking channel of monetary policy in the US. 


\section{Empirical Model and Variable Description}

In this study, the researcher focuses on investigating the relationships among monetary policy, bank liquidity and shadow banking using a panel of 15 emerging economy countries. Cross border liabilities of banks are an alternative liquidity source to bank deposits and are vulnerable to both changes in economic conditions in the source country and also in destination country. Panel data framework is preferred due its robustness over both time series and cross sectional analyses. The study follows previous studies on monetary policy, which employ the vector autoregressive model (VAR) (Sims, 1980, Nelson et al., 2018). However, since we are using panel data, the study estimates a panel vector autoregressive model (PVAR). A PVAR accounts for country fixed effects and uses GMM instruments to deal with Endogeneity. We report on granger causality tests, impulse response functions and forecast error variance decompositions. As argued in literature (Kilian, 2011, Stock and Watson, 2001) these analyses are more informative than estimated coefficients in a VAR.

Panel VAR Model: In basic panel VARs, all variables are endogenous to the system like in the time series VARs. Thus all variables are interdependent and shock transmissions can be identified. The technique uses GMM-like instruments to deal with Endogeneity of the regressors and thus overcome the Nickell (1981) bias. The following is a panel VAR representation:

Where, $\quad i=1, \ldots \ldots, N$ and $t=1 \ldots \ldots, T$

$$
y_{i t}=A_{o i}(t)+A_{i}(l) Y_{t-1}+\mu_{i t}, \#(2)
$$

$y_{i t}$ is the vector of endogenous variables in each unit (e.g. in a country) and $Y_{t}$ is therefore a stacked version of $y_{i t}$ and $\mu_{i t}$ is a vector of random disturbances, assumed to be white noise. According to Canova and Ciccarelli (2013), there are three distinguishing features of equation (2); firstly it portrays dynamic interdependency, which is the fact that information of past periods is captured in the model through lags of all endogenous variables. The second characteristic is that of static interdependence, which is explained by correlation amongst the different units' $\mu_{i t}$. The third characteristic is cross sectional heterogeneity - the slope, the intercept and variance of shocks $\mu_{i t}$ are different for each unit.

Model Variables and Data: The data used in the study covers the period 1998Q2 to 2015Q1. The sample period is constrained by the unavailability of shadow banking data in some jurisdictions beyond 1998. The following model shall be estimated for the four countries following Love and Zicchino (2006).

$$
y_{i t}=A_{o i}(t)+A_{i}(l) Y_{t-1}+\mu_{i t}, \#(3)
$$

where $y_{i t}$ is a vector of the following 6 variables, $A_{i}$ is a matrix of parameters and $\varepsilon_{t}$ are white noise innovations. The model variables are described in Table 1 below.

Table 1: Variable Description

\begin{tabular}{cll}
\hline Variable & Description & Data Source \\
\hline Infl & Inflation & Central banks/IMF \\
Sbcorr & shadow banking/non-core liabilities & BIS/FSB \\
GDPn & Nominal GDP & World bank \\
Reer & Real Effective Exchange rate & IMF/Smith and Galesi (2014) \\
Liquid & Liquidity measure - M1 & IMF/World bank \\
Pr & Central Bank policy rate & BIS \\
\hline
\end{tabular}

Shadow Banking Measure: Shadow banking is mainly constructed using data from the $\mathrm{FSB}^{3}$ on assets of other financial intermediaries and data on foreign liabilities from the BIS for four countries that do not participate in the FSB Shadow Bank Monitoring programme. The data is transformation logarithms and

${ }^{3}$ We mainly use data from BIS on foreign liabilities of banks. Where the data is not available, we use data on shadow bank assets from FSB. The FSB is extrapolated from annual frequency to quarterly frequency following Smith and Galesi (2014) in Eviews. The results presented here are robust to the use of annual data for all variables and annual shadow bank data from FSB. The results of the robustness model are available on request. 
measured as growth in shadow bank assets. Reported results show a positive association between the interest rate and shadow banking implying that shadow banking increases as bank liquidity decreases (Barbu et al., 2016, Altunbas et al., 2009). Their studies do not however take into account the bi-directional effect that can exist between the two variables.

Data for Countries: The country sample for the study is provided in Table 2. We include Singapore amongst 14 emerging economies due to its proximity to emerging countries in Asia. Our sample size consists mainly of emerging economies; however, the sample is constrained by lack of data on our shadow banking measures for other countries.

Table 2: Country Sample

\begin{tabular}{lll}
\hline Argentina & Malaysia & Thailand \\
\hline Brazil & Mexico & India \\
Chile & Philippines & South Africa \\
China & Peru & Saudi Arabia \\
Indonesia & Singapore & Turkey \\
\hline
\end{tabular}

\section{Empirical Results}

We provide in this section a concise description of the results from the panel VAR model. We take into account the presence of cross sectional dependency in the sample, by employing Pesaran's PESCADF (2007) unit root test to test for stationarity of each variable. Two advantages of this unit root test are that it accounts for cross sectional dependence and is applicable in unbalanced panels. Thus the following procedure is followed to obtain the results: Preliminary univariate analysis of data, cross sectional dependence test, unit root tests and then estimation of panel VAR.

Descriptive Statistics: We provide summary statistics for all the 15 countries in the sample in Table 3. It is noteworthy to mention that variables used in the estimation are logarithms in the cases of inflation (logarithm of the consumer price index), gdpn (logarithm of nominal GDP in US\$ terms), reer (logarithm of the country specific reer), shadow banking (logarithm of OFI assets of bank foreign liabilities) and liquidity (liquid) is the logarithm of M1 or M2 depending on available country data. This transformation is important for basically two reasons, firstly to avoid outliers in the data and secondly to minimise the possibility of heteroskedastic errors from the estimation. From Table 3, all data presented show consistence in terms of low standard deviations and shorter ranges. The number of observations for both sbscorr and liquid show that the panel is unbalanced as it is less than the maximum number expected per variable from all the countries.

Table 3: Summary Statistics

\begin{tabular}{llllll}
\hline Variable & Observations & Mean & Std. Dev & Min & Max \\
\hline Sbscorr & 1.097 & 10.68576 & 0.6669625 & 8.7717 & 12.98063 \\
Liquid & 1.104 & 551.5009 & 318.8401 & 1 & 1103 \\
Infl & 1.125 & 1.811522 & 0.495537 & -0.0105076 & 2.209343 \\
Gdpn & 1.125 & 4.940878 & 0.3239192 & 4.415491 & 6.264406 \\
Pr & 1.125 & 0.069643 & 0.0860626 & 0 & 2.000267 \\
Reer & 1.125 & 1.793163 & 0.3476365 & 05895266 & 2.82597 \\
\hline
\end{tabular}

Correlation Matrix: Table 4 below shows individual correlations for all variables used in the model. As expected, we see a very high correlation coefficient for liquidity and inflation. All other correlations are below 0.5 reducing the possibility of multi-collinearity. 
Table 4: Correlation Table

\begin{tabular}{lllllll}
\hline \multicolumn{2}{l}{ Sample: 1998Q2 2015Q1 } & & & & \\
\hline Correlation & REER & SBSCORR & PR & LIQUID & GDPN & INFL \\
\hline REER & 1.000000 & & & & & \\
SBSCORR & -0.044901 & 1.000000 & & & & \\
PR & -0.152604 & 0.036007 & 1.000000 & & & \\
LIQUID & -0.236705 & 0.238839 & 0.237018 & 1.000000 & & \\
GDPN & -0.022537 & 0.471653 & -0.164176 & 0.177695 & 1.000000 & \\
INFL & 0.179980 & 0.045384 & -0.323402 & -0.846239 & 0.222644 & 1.000000 \\
\hline
\end{tabular}

Cross Sectional Dependence Test: According to Sarafidis and Wansbeek (2012) cross sectional dependence refers to the presence of correlation across panels. Most panel data estimation methods assume cross sectional independence and the presence of cross sectional dependence can influence the estimated results (Comunale, 2017). Sarafidis and Wansbeek (2012) argue that cross sectional dependence can result in biased and inconsistent results. In addition, traditional panel unit root tests do not account for cross sectional dependence. However, in many macro panels cross sectional dependence exists (Pesaran, 2007, Sarafidis and Wansbeek, 2012). The study applies Pesaran (2004)'s cross sectional dependence test and the results are presented in Table 5.

Table 5: Cross Sectional Dependence Test

\begin{tabular}{lll}
\hline Variable & CD-test stat & P-value \\
\hline Dpr & 9.50 & 0.000 \\
Dsbscorr & 22.16 & 0.000 \\
Dgdpn & 24.20 & 0.000 \\
Dliquid & 17.36 & 0.000 \\
Dreer & 42.58 & 0.000 \\
Dinfl & 7.68 & 0.000 \\
\hline
\end{tabular}

Table 5 shows that for all variables, the null hypothesis of cross sectional independence can be rejected. Thus all variables exhibit cross sectional dependence. In the next section, the study tests for stationarity of variables taking into consideration cross sectional dependence in the spirit of Pesaran (2007).

Panel Unit Root Tests: Our work utilises Pesaran (2007) panel unit root test. The tests account for cross sectional dependence by augmenting the Augmented Dickey Fuller (ADF) regressions with panel averages of lagged values and first differences of the series. It is noteworthy that using data at levels does not show any non-negligible difference in the simulated IRFs. The estimation method follows Love and Zicchino (2006) and Abrigo and Love (2016). The method accounts for country specific individual unobservable characteristics using fixed effects. The null hypothesis in the test is that the series are non-stationary. As shown in Table 6, we conclude that all series in the model are non-stationary ant level. However, all differenced series show evidence of stationarity, specifically all series are integrated of order one I (1).

Table 6: Unit Root Tests

\begin{tabular}{llll}
\hline Variable & Levels & 1 $^{\text {st }}$ Diff & Conclusion \\
\hline REER & -1.117 & $-6.275^{* * *}$ & $\mathrm{I}(1)$ \\
SBSCORR & 0.819 & $-7.161^{* * *}$ & $\mathrm{I}(1)$ \\
PR $^{\mathrm{T}}$ & -0.173 & $-8.825^{* * *}$ & $\mathrm{I}(1)$ \\
LIQUID $^{\mathrm{T}}$ & -0.796 & $-3.201^{* * *}$ & $\mathrm{I}(1)$ \\
GDPN & 3.542 & $-6.412^{* * *}$ & $\mathrm{I}(1)$ \\
INFL & -1.056 & $-6.544^{* * *}$ & $\mathrm{I}(1)$ \\
\hline
\end{tabular}

T refers to inclusion of a time trend. ${ }^{*},{ }^{* *},{ }^{* * *}$ refers to $10 \%, 5 \%$ and $1 \%$ significance level respectively. 
PVAR Estimation Results: This section reports results from the panel VAR estimates. Full estimation results are attached in Appendix A. The presence of unit roots in our main data set requires that we estimate the VAR in differences. However, in order to overcome the Nickell (1981) bias where correlation between the error term and lagged values of the dependent variable exist, Helmert transformation is used. Helmert procedure removes fixed effects using forward mean differencing, preserving orthogonality between the transformed variables and lagged variables and helps to reduce serial correlation (Hove et al., 2015). The model is estimated using the method of generalised methods of moment (GMM). Cholesky decomposition is used for identification in both IRFs and FEVD. We follow Dajcman (2016) and Dajcman and Tica (2017) who suggest the following order of variables: MACROECONOMIC variables, MONETARY variables and then BANK SPECIFIC variables. The ordering assumes that macroeconomic variables are the most exogenous and in turn influence monetary variables, which also influence financial or bank specific variables. According to Dajcman and Tica (2017) it is important to identify all monetary policy channels in order to develop optimal monetary policy. They argue that unidentified channels can dampen the monetary policy impulses, reducing the intended impact of a policy shift. Thus our variables are ordered as follows: reer - GDPn - pr - infl - sbscorr liquidity.

PVAR Lag Order Selection: Lag selection is done following Abrigo and Love (2016) and a PVAR of lag order 2 is selected. Table 7 presents results of the lag selection criterion. We follow the lag order as selected by the MAIC selection criterion suggested by Andrews and Lu (2001).

Table 7: PVAR Lag Order Selection

\begin{tabular}{lllllll}
\hline Lag & CD & J-STA & J-P Value & MBIC & MAIC & MQIC \\
\hline 1 & 0.95 & 91.73 & 0.092 & -422.88 & -58.26 & -197.15 \\
2 & 0.85 & 37.89 & 0.895 & -305.19 & -62.10 & -154.70 \\
3 & -24.42 & 16.29 & 0.905 & -155.24 & -33.70 & -79.99 \\
\hline
\end{tabular}

PVAR Model Stability: Model stability is checked using the AR roots graph. Figure 1 shows the AR roots graph for the estimated model. It indicates that the model is stable as all roots are inside the circle. Furthermore, the study tests the model for over identifying restrictions using Hansen's J-statistic. The coefficient of the J-statistic is found to be $88.88(\mathrm{p}=0.086)$, which is not significant at the $5 \%$ level. Therefore, we can conclude that the GMM instruments are valid.

\section{Figure 1: AR Roots Graph}

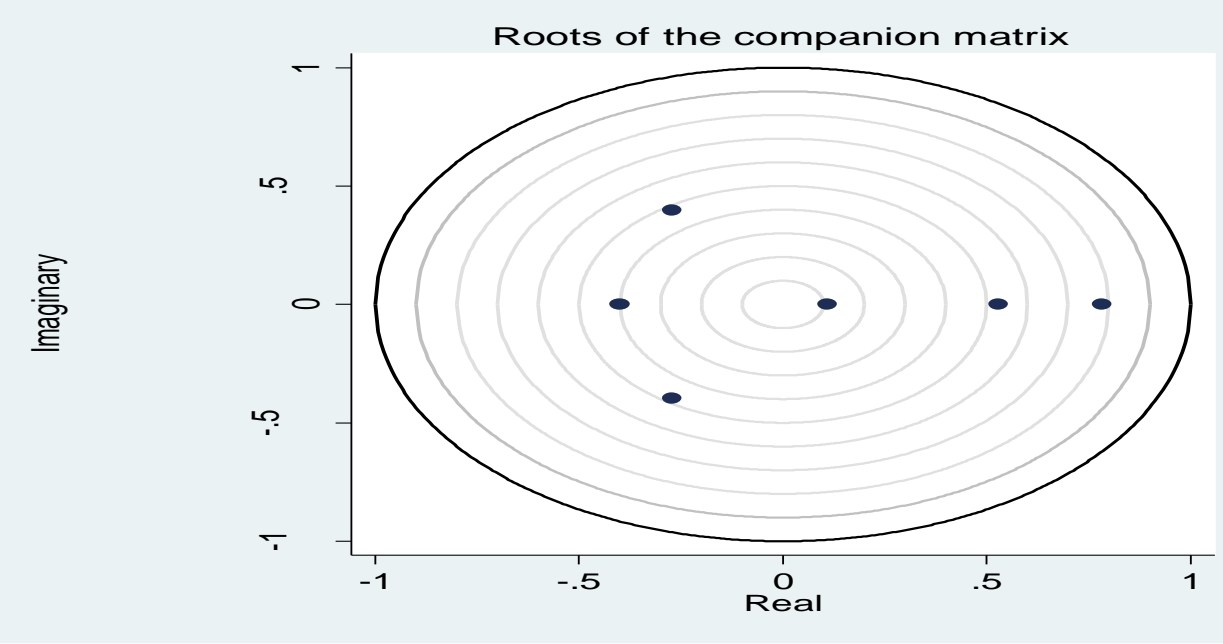

Granger Causality Tests: Panel granger causality tests were undertaken after estimating the panel VAR model and the results are presented in Table 8. The null hypothesis is that the excluded variable (left hand variable) does not granger cause the equation variable (right hand variable). Thus the alternative hypothesis is that the excluded variable granger causes the equation variable. 
Table 8: Panel VAR Granger Causality Test

\begin{tabular}{llll}
\hline & Hypothesis & Chi2 stat & P-value \\
\hline 1 & dpr does not granger cause dsbscorr & 5.18 & 0.023 \\
2 & dliquid does not granger cause dsbscorr & 230.44 & 0.000 \\
3 & dsbscorr does not granger cause dpr & 0.14 & 0.712 \\
4 & dliquid does not granger cause dpr & 1.53 & 0.216 \\
5 & dsbscorr does not granger cause dliquid & 8.13 & 0.004 \\
6 & dpr does not granger cause dliquid & 0.024 & 0.878 \\
\hline
\end{tabular}

The granger causality tests in table 8 show that lagged values of policy rate and bank liquidity granger cause shadow banking. Furthermore, shadow banking and the policy rate depicts a uni-directional relationship. The implication would be that monetary policy stance impact shadow bank activity but the reverse is not true. This proposition has been suggested in Borio and Zhu (2012) on the who argues that changes in the monetary policy stance have a bearing on financial market agents' risk taking. In addition, the study establishes a bidirectional relationship between shadow banking and bank liquidity as measured by $m 1$.

Impulse Response Functions: This section reports on cumulative impulse response functions from the estimated PVAR model. Three shocks are simulated, a monetary policy shock, a shock to shadow banking and a shock to bank liquidity. These are discussed separately below.

(A) Impulse Responses to a 1 Standard Deviation Shock to Shadow Banking: Figure 2 shows the response of other variables to a shock in shadow banking. A positive shock in shadow banking results in an increase in bank liquidity as measured by the money supply. This could imply shadow banking has a complementary effect on the liquidity of banks, with increased participation of shadow banks in financial activities increasing bank deposits. On the other hand, banks could also be taking advantage of wholesale markets to raise finance from the shadow banking system, which substitutes bank deposits in credit creation hence they are able to extend credit whilst at the same time increasing their stock of liquid liabilities. Viewed from either side, shadow banking complementary effect on bank liquidity implies banks do not entirely depend on central bank money and deposit creation for funding. The finding supports evidence in Loutskina (2011), who demonstrate that securitisation increases bank liquidity and decrease the elasticity of bank credit creation to changes in bank deposits.

The response of the policy rate to an innovation in shadow banking portrays mean reversion around the zero $\mathrm{x}$-axis. Thus initially there is a rise in the policy rate in response to a shock in shadow banking. The mean reverting shape indicates there is over-correction of the changes in the policy rate. A shock to shadow banking also results in depreciation of the domestic currency. The depreciation of the domestic currency as a result of a shock in shadow banking could be indicative of the cross border nature of shadow banking activities. The results supports findings of Zhou and Tewari (2019a) who conclude that there is a close association between changes in shadow banking activities and international capital flow changes, leading to currency depreciation/appreciation.

Figure 2: Impulse Responses to a 1 Standard Deviation Shock in Shadow Banking

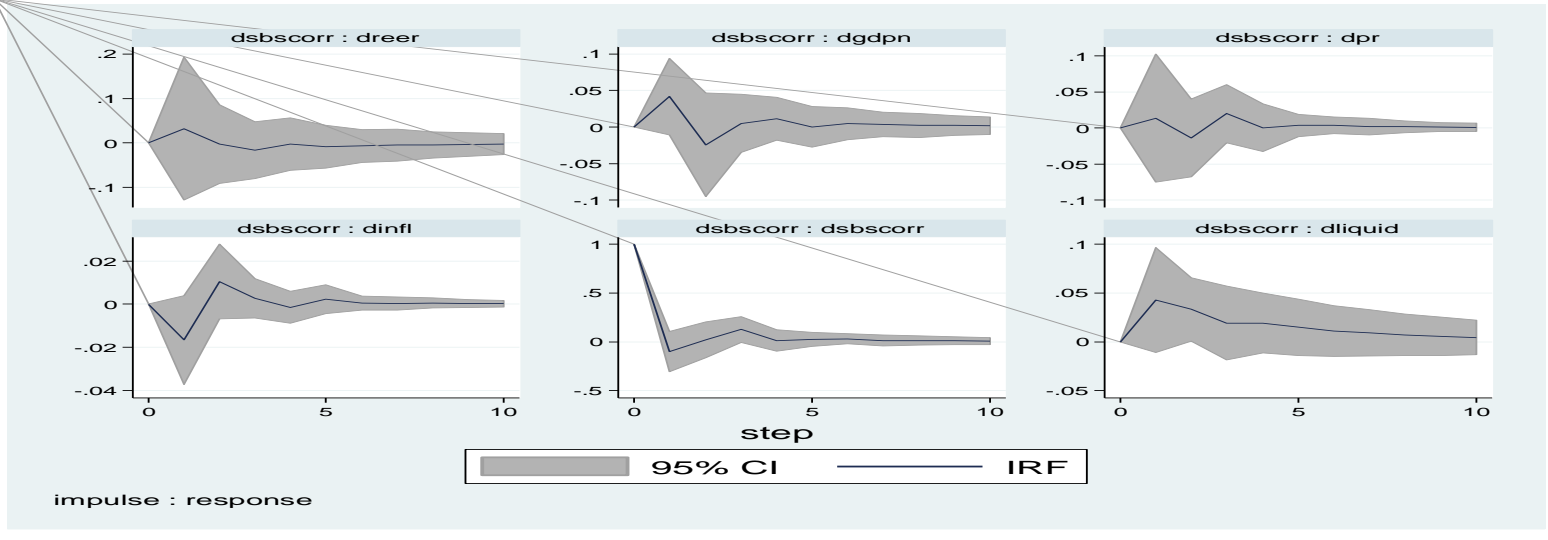


Impact of shadow bank shocks on both inflation and GDP is very small as shown in the graph, which may be interpreted as not significant. The direction of the shocks however may give an important insight into the relationships amongst these variables. For instance, a shock in shadow banking induces a decrease in inflation rate in emerging economies. This finding may indicate the reduction in consumption as funds are transferred from consumers into financial markets for investment purposes as shadow banks grow. A shock in shadow banking also induce an increase in GDP, a finding in tandem with the Granger causality tests above, which established a uni-directional relationship between GDP and shadow banking flowing from shadow banking. The results supports literature on financial innovation and economic growth, which suggests that financial innovation increases economic growth (Bara et al., 2016, Beck et al., 2014, Laeven et al., 2015).

\section{Figure 3: Response to a 1 Standard Deviation Innovation in the Policy Rate}

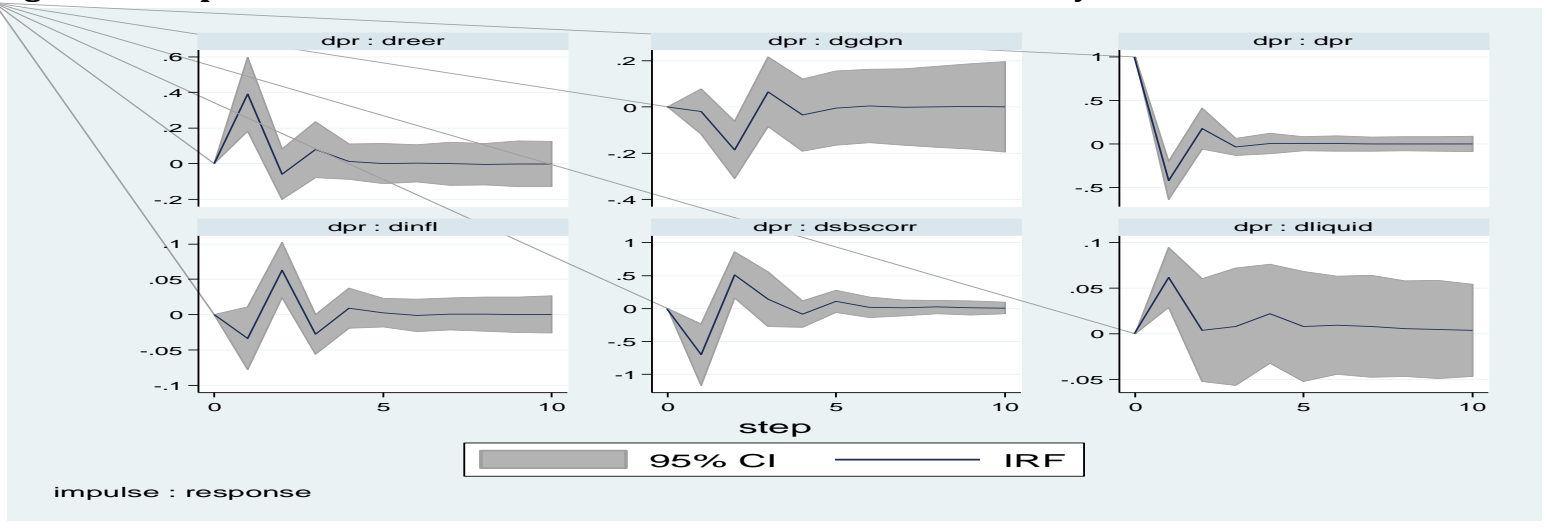

(B) Impulse Responses to a 1 Standard Deviation Shock to the Monetary Policy Rate: Figure 3 shows results of the response to a shock in the policy rate. Contractionary monetary policy shock induces a decrease in shadow banking. However, the decline is short lived. The finding is first of all contrary to other studies such as Nelson et al. (2018) and Funke et al. (2015) whose findings suggest an increase in shadow banking in the event of a positive shock in the policy rate. However, our results are in support of the risk-taking proposition, which suggest that increasing the policy rate increases risk and in turn make market participants to reduce their appetite for risky assets. The dominance of the risk-taking proposition could suggest that shadow banking is not substitutes for bank liquid liabilities in emerging economies. This second explanation is supported by the finding that bank liquidity increases with a shock to shadow banking and the work of Loutskina (2011) who reports that securitisation increases bank liquidity. We argue that the impact of monetary policy on shadow banking is different in developed vs emerging or developing economies.

A positive shock to the policy rate leads to in an immediate increase in bank liabilities contrary to theoretical expectations. The increase is however short-lived and followed by a deep decrease. Thus in the presence of shadow banking money supply does not respond to the policy rate immediately but with a lag. Instead, it can be shown that the policy rate impact shadow banks negatively first before bank liquidity begins to dwindle. Our explanation for this finding points to banks participation in shadow banking and sudden withdrawal of shadow banking liabilities in the event of a monetary policy shock. Formal banking institutions respond to a monetary policy shock by reducing shadow banking asset holdings converting them to accessible liabilities on their balance sheets. A contractionary monetary policy shock however, decreases both inflation and GDP growth as expected. In theory, tight monetary policy is used against an overheated economy, reducing both the price level and output (Klaeffling, 2003). We therefore confirm the overall potency of monetary policy in emerging economies. this finding is supported by previous empirical works on monetary policy (Gambacorta et al., 2014).

(C) Impulse Responses to a 1 Standard Deviation Shock to Bank Liquidity (m1): In this section, the study analyses response to a shock in bank liquidity a positive shock in bank liquidity increases shadow bank assets growth. Again this confirms the complementarity between bank liquidity and shadow banking in emerging economies. This can be explained by the role formal banks in shadow banking sectors of emerging market economies. We proffer two explanations; firstly, commercial banks have a parent/subsidiary relationship 
with shadow banks. A decrease in funding in the parent company would also negatively affect the subsidiary. The second explanation could be the importance of formal banking institutions as financiers of shadow banking activity in emerging markets. We agree with the findings of Acharya et al. (2013), who argue that shadow banking in emerging market economies derives its funding from commercial banks. Intuitively, a reduction of commercial bank funding will therefore have a negative effect on shadow bank growth and viceversa.

\section{Figure 4: Response to a 1 Standard Deviation Innovation in Bank Liquidity}

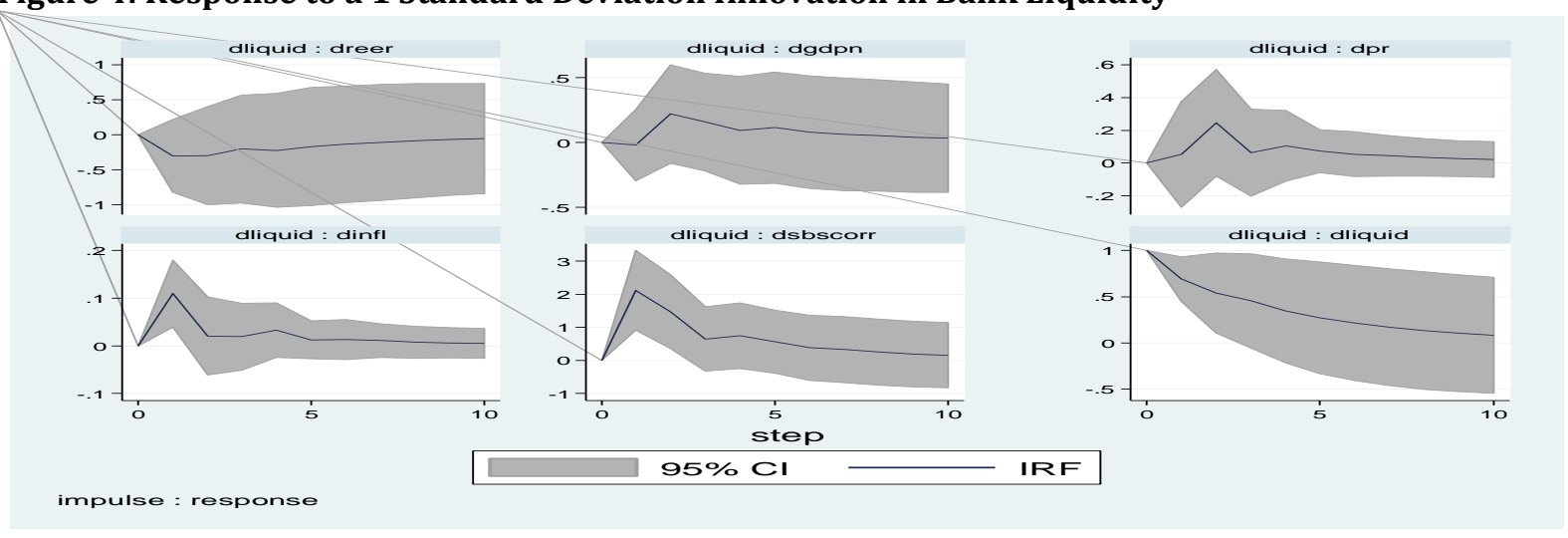

A shock in bank liquidity also induces the monetary authorities to raise the policy rate as indicates in the second panel of Figure 4. However, the effect is small and almost insignificant. A positive shock in liquidity is however shown to be important in driving economic growth during the first and second quarters, only to dissipate sharply after the second quarter. The finding confirms the short-run potency of monetary policy in driving real activity. Inflation rate explains about $9.4 \%$ of the variability in the policy rate. The other variables do not explain a significant portion of the variability in the policy rate. Variability in shadow baking is also to a greater extent explained by it. Again a positive shock to money supply, driven by lower interest rates could be accompanied by an outward capital flow. Lastly variability in the exchange rate is explained by changes in GDP, inflation and the policy rate. The capital outflow results in currency depreciation as shown by an upward movement in the REER. There is however, a small appreciation before the exchange rate starts depreciating. The effect of a shock in bank liquidity on inflation is positive in line with theoretical expectations.

Forecast Error Variance Decompositions (FEVD): This section report results on FEVD. The results are displayed in Table 9 below. Response variables as selected are the policy rate, shadow banking and bank liquidity. The main result from the study is that in both the short-run and the long-term, variability in these variables is driven by the variables themselves. The rate of inflation and GDP have significant influence on the policy rate however, with approximately $1.5 \%$ variation being explained by GDP in the short-run. Notable contributions to variations in shadow banking however, are drawn from GDP, inflation and the policy rate. For instance, after 10 periods (10 quarters), GDP contributes about 3.3\% of the variation in SBSCORR, INFL contributes about $2 \%$ and the policy rate contributes about $1.9 \%$ to variation in shadow banking. The last variable of interest is bank liquidity. Variation in bank liquidity is also mostly explained by itself. Variability in both inflation and GDP is explained by the variation in the policy rate and the exchange rate (REER). For instance, about $4.2 \%$ of the variation in REER in the $10^{\text {th }}$ period is explained by the policy rate. GDP and Inflation explain approximately $11.8 \%$ and $3.1 \%$ of the variation in the REER respectively. 
Table 9: Forecast Error Variance Decompositions ${ }^{4}$

\begin{tabular}{cllllll}
\hline $\begin{array}{l}\text { Response } \\
\text { Variable }\end{array}$ & \multicolumn{6}{l}{ Impulse Variable } \\
& dpr & dgdpn & dliquid & dinfl & dreer & dsbscorr \\
$\Delta d p r$ & 0.88 & 0.015 & 0.0005 & 0.094 & 0.0007 & 0.0001 \\
$\Delta$ sbscorr & 0.019 & 0.033 & 0.001 & 0.021 & 0.012 & 0.92 \\
$\Delta$ liquid & 0.0004 & 0.004 & 0.99 & 0.0003 & 0.0013 & 0.0002 \\
$\Delta$ gdpn & 0.15 & 0.94 & 0.008 & 0.005 & 0.02 & 0.000008 \\
$\Delta$ infl & 0.042 & 0.008 & 0.0002 & 0.93 & 0.01 & 0.0002 \\
reer & 0.042 & 0.12 & 0.007 & 0.031 & 0.79 & 0.003 \\
\hline
\end{tabular}

*The results presented are for period 10 or 10 quarters, which can be used to indicate short run responses. The variances do not change significantly with longer time periods.

\section{Conclusion}

The study provides insight into the linkages between shadow banking, bank liquidity and monetary policy in emerging countries. The results indicate a weak response of monetary policy to developments in the shadow banking sector. Using Granger causality tests, impulse response functions and FEVD, the study shows that monetary policy does not respond to a shock in shadow banking. To the contrary, we find compelling evidence that shadow banking responds to changes in the monetary policy rate. This results points to the existence of a shadow banking channel of monetary policy as proffered by Xiao (2018). However, contrary to previous studies, increases in the policy rate result in an immediate decrease in shadow banking activity. We also find that bank liquidity responds to shocks in the policy rate as expected from literature, with a hike in the policy rate dampening bank liquidity. Our findings indicate the potency of monetary policy in emerging economies. In addition, a shock to bank liquidity lead to increased shadow banking. The economic significance of this finding is that strong linkages should exist between shadow banks and commercial banks for these results to be valid. Our findings also indicate the dominance of the risk taking proposition in emerging economies. We also find a shock in shadow banking to increase bank liquidity. The result shows that banks are able to raise more liquid liabilities from the shadow banking sector and vice-versa.

The study's findings show that monetary policy has an influence on the financial sector and by extension on financial stability through its effect on shadow banking. Analysis and conduct of monetary policy that does not account for its influence on financial variables may lead to a less optimum policy stance being taken. We recommend policy coordination between monetary and prudential authorities to minimise effect of negative shocks emanating from the shadow banking sector. In addition, international cooperation aimed at achieving financial stability could assist monetary authorities in emerging economies in taking into consideration movements in international financial markets when implementing monetary policy.

\section{References}

ABRIGO, M. R. \& LOVE, I. (2016). Estimation of panel vector autoregression in Stata. Stata Journal, 16, 778804.

ACHARYA, V. V., KHANDWALA, H. \& ÖNCÜ, T. S. (2013). The growth of a shadow banking system in emerging markets: Evidence from India. Journal of International Money and Finance, 39, 207-230.

ADRIAN, T. \& ASHCRAFT, A. B. (2016). Shadow banking: a review of the literature. Banking Crises. Springer.

ADRIAN, T. \& SHIN, H. S. 2009. Money, liquidity, and monetary policy. American Economic Review, 99, 600605.

AFTAB, Z. \& VAROTTO, S. (2017). Liquidity and Shadow Banking. Reading, UK: University of Reading.

ALTUNBAS, Y., GAMBACORTA, L. \& MARQUES-IBANEZ, D. (2009). Securitisation and the bank lending channel. European Economic Review, 53, 996-1009.

ANDREWS, D. W. \& LU, B. (2001). Consistent model and moment selection procedures for GMM estimation with application to dynamic panel data models. Journal of Econometrics, 101, 123-164.

\footnotetext{
${ }^{4}$ Full results are provided in the Appendix.
} 
BARA, A., MUGANO, G. \& LE ROUX, P. (2016). Financial innovation and economic growth in the SADC. African Journal of Science, Technology, Innovation and Development, 8, 483-495.

BARBU, T. C., BOITAN, I. A. \& CIOACA, S. I. (2016). Macroeconomic determinants of shadow banking-evidence from EU countries. Review of Economic and Business Studies, 9, 111-129.

BECK, T., CHEN, T., LIN, C. \& SONG, F. M. (2014). Financial innovation: The bright and the dark sides. Available at SSRN 1991216.

BERNANKE, B. S., GERTLER, M. \& GILCHRIST, S. (1999). The financial accelerator in a quantitative business cycle framework. Handbook of macroeconomics, 1, 1341-1393.

BORIO, C. \& ZHU, H. (2012). Capital regulation, risk-taking and monetary policy: a missing link in the transmission mechanism? Journal of Financial stability, 8, 236-251.

BRUNO, V. \& SHIN, H. S. (2014). Cross-border banking and global liquidity. The Review of Economic Studies, $82,535-564$.

CANOVA, F. \& CICCARELLI, M. (2013). Panel Vector Autoregressive Models: A Survey is The views expressed in this article are those of the authors and do not necessarily reflect those of the ECB or the Eurosystem. VAR Models in Macroeconomics-New Developments and Applications: Essays in Honor of Christopher A. Sims. Emerald Group Publishing Limited.

CHEN, K., REN, J. \& ZHA, T. (2017). The nexus of monetary policy and shadow banking in china. National Bureau of Economic Research.

CHEN, M. J. \& COLUMBA, M. F. (2016). Macroprudential and monetary policy interactions in a DSGE model for Sweden, International Monetary Fund.

COMUNALE, M. (2017). A panel VAR analysis of macro-financial imbalances in the EU. European Central Bank.

DAJCMAN, S. (2016). The Bank Lending Channel of Monetary Policy and its Macroeconomic Effects: Evidence from a Sample of Selected Euro Area Countries. Engineering Economics, 27, 124-133.

DAJCMAN, S. \& TICA, J. (2017). The broad credit and bank capital channels of monetary policy transmission in the core and peripheral Euro Area. Zbornik radova Ekonomskog fakulteta u Rijeci: časopis za ekonomsku teoriju i praksu, 35, 249-275.

DE MORAES, C. O., MONTES, G. C. \& ANTUNES, J. A. P. (2016). How does capital regulation react to monetary policy? New evidence on the risk-taking channel. Economic Modelling, 56, 177-186.

DE NICOLÒ, G., DELL'ARICCIA, G., LAEVEN, L. \& VALENCIA, F. (2010). Monetary Policy and Bank Risk Taking. Washington DC: International Monetary Fund.

FSB 2017. Global shadow banking monitoring report (2017). Basel: Financial Stability Board. Available at www.fsb.org/2018/03/global-shadow-banking-monitoring-report-2017/.

FUNKE, M., MIHAYLOVSKI, P. \& ZHU, H. (2015). Monetary policy transmission in China: A DSGE model with parallel shadow banking and interest rate control. BOFIT Discussion Papers, 2015, 1.

GALÍ, J. (2015). Monetary policy, inflation, and the business cycle: an introduction to the new Keynesian framework and its applications, Princeton University Press.

GAMBACORTA, L. (2009). Monetary policy and the risk-taking channel. International banking and financial market developments, 3,43 .

GAMBACORTA, L., HOFMANN, B. \& PEERSMAN, G. (2014). The effectiveness of unconventional monetary policy at the zero lower bound: A cross-country analysis. Journal of Money, Credit and Banking, 46, 615-642.

GE, L. B. W. (2011). On the Credit Creation of Shadow Banking and Its Impact on the Monetary Policy [J]. Journal of Financial Research, 12, 008.

GERTLER, M. \& KARADI, P. (2011). A model of unconventional monetary policy. Journal of monetary Economics, 58, 17-34.

HAISEN, H. \& YAZDIFAR, H. (2015). Impact of the shadow banking system on monetary policy in China. ICTACT Journal on Management Studies, 1, 1-12.

HELLWIG, M. (2015). Financial stability and monetary policy. Bonn: Max Planck Institute for Research on Collective Goods. Available at https://www.coll.mpg.de/pdf_dat/2014_09online.pdf.

HOVE, S., MAMA, A. T. \& TCHANA, F. T. (2015). Monetary policy and commodity terms of trade shocks in emerging market economies. Economic Modelling, 49, 53-71.

KILIAN, L. (2011). Structural Vector Autoregressions. CEPR Discussion Papers.

KLAEFFLING, M. (2003). Monetary policy shocks-a nonfundamental look at the data. ECB Working Paper.

KNOOP, T. A. (2008). Modern financial macroeconomics: panics, crashes, and crises, Wiley-Blackwell. 
LAEVEN, L., LEVINE, R. \& MICHALOPOULOS, S. (2015). Financial innovation and endogenous growth. Journal of Financial Intermediation, 24, 1-24.

LOUTSKINA, E. (2011). The role of securitization in bank liquidity and funding management. Journal of Financial Economics, 100, 663-684.

LOVE, I. \& ZICCHINO, L. (2006). Financial development and dynamic investment behavior: Evidence from panel VAR. The Quarterly Review of Economics and Finance, 46, 190-210.

MAZELIS, F. (2014). Monetary Policy Effects on Financial Intermediation via the Regulated and the Shadow Banking Systems. Humboldt University, Collaborative Research Center 649.

MOREIRA, A. \& SAVOV, A. (2017). The macroeconomics of shadow banking. The Journal of Finance, 72, 23812432.

NELSON, B., PINTER, G. \& THEODORIDIS, K. (2018). Do contractionary monetary policy shocks expand shadow banking? Journal of Applied Econometrics, 33, 198-211.

NICKELL, S. (1981). Biases in dynamic models with fixed effects. Econometrica: Journal of the Econometric Society, 1417-1426.

PALIGOROVA, T. \& SANTOS, J. A. 2017. Monetary policy and bank risk-taking: Evidence from the corporate loan market. Journal of Financial Intermediation, 30, 35-49.

PESARAN, M. H. (2004). General diagnostic tests for cross section dependence in panels. CESifo Working Paper.

PESARAN, M. H. (2007). A simple panel unit root test in the presence of cross-section dependence. Journal of applied econometrics, 22, 265-312.

SARAFIDIS, V. \& WANSBEEK, T. (2012). Cross-sectional dependence in panel data analysis. Econometric Reviews, 31, 483-531.

SIMPASA, A., NANDWA, B. \& NABASSAGA, T. (2014). Bank Lending Channel of Monetary Policy Transmission in Zambia: Evidence from Bank-Level Data.

SIMS, C. A. (1980). Macroeconomics and reality. Econometrica: Journal of the Econometric Society, 1-48.

SMETS, F. (2014). Financial stability and monetary policy: How closely interlinked? International Journal of Central Banking, 10, 263-300.

SMITH, L. \& GALESI, A. (2014). GVAR Toolbox 2.0. University of Cambridge: Judge Business School.

STOCK, J. H. \& WATSON, M. W. (2001). Vector autoregressions. The Journal of Economic Perspectives, 15, 101115.

VERONA, F., MARTINS, M. \& DRUMOND, I. (2013). (Un) anticipated Monetary Policy in a DSGE Model with a Shadow Banking System. International Journal of Central Banking, 9, 78-124.

XIANG, Q. \& QIANGLONG, Z. (2014). Shadow Banking and Monetary Policy Transmission. Economic Research Journal, 5, 008.

XIAO, K. (2018). Monetary Transmission in Shadow Banks. New York: Columbia Business School. Available online at http://utahwfc.org/uploads/2018_paper_04d.pdf.

ZHOU, S. \& TEWARI, D. D. (2019a). Shadow banking, cross-border shocks, and financial stability in emerging economies: a global VAR analysis. African Journal of Business and Economic Research, 14, 159-184.

ZHOU, S. \& TEWARI, D. D. (2019b). Shadow Banking, Risk Taking and Monetary Policy in Emerging Countries: A Panel Cointegration Approach. Cogent Economics \& Finance, 1636508. 


\section{APPENDIX: PVAR Estimation Results}

Final GMM Criterion $Q(b)=$
Initial weight matrix: Identity

\begin{tabular}{|c|c|c|c|c|c|c|}
\hline & & & & & $\begin{array}{l}\text { f obs } \\
\text { f pane1s } \\
\text { no. of T T }\end{array}$ & $\begin{array}{r}1045 \\
15 \\
69.667\end{array}$ \\
\hline & Coef. & sta. Err. & $z$ & $P>|z|$ & [95: Conf. & Intervalu \\
\hline \multicolumn{7}{|l|}{$\begin{array}{c}\text { dsbscorr } \\
\text { dsbscort }\end{array}$} \\
\hline & .0123327 & .0088113 & 1.40 & 0.162 & -.0049371 & .0296025 \\
\hline $\begin{array}{l}\text { dinfl } \\
\text { II. }\end{array}$ & .9164653 & .0880238 & 10.41 & 0.000 & .7439419 & 1.088989 \\
\hline $\begin{array}{l}\text { dgdpn } \\
\text { L1. }\end{array}$ & 1.372521 & .1462109 & 9.39 & 0.000 & 1.085953 & 1.659089 \\
\hline $\begin{array}{l}\text { dreer } \\
\text { L1. }\end{array}$ & .07825 & .0394034 & 1.99 & 0.047 & .0010208 & .1554793 \\
\hline $\begin{array}{l}\mathrm{dpr} \\
\mathrm{L} 1 .\end{array}$ & -.2721153 & .0221154 & -12.30 & 0.000 & -.3154606 & -.2287699 \\
\hline $\begin{array}{c}\text { diquid } \\
\text { LI. }\end{array}$ & .0225069 & .0021469 & 10.48 & 0.000 & .0182991 & .0267147 \\
\hline \multicolumn{7}{|l|}{$\begin{array}{l}\text { dinfl } \\
\text { dsbscorr }\end{array}$} \\
\hline $\begin{array}{l}\text { dinfl } \\
\text { II. }\end{array}$ & -.2040192 & .0240097 & -8.50 & 0.000 & -.2510772 & -.1569611 \\
\hline $\begin{array}{l}\text { dgdpn } \\
\text { L1. }\end{array}$ & .0420342 & .014809 & 2.84 & 0.005 & .013009 & .0710594 \\
\hline $\begin{array}{l}\text { dreer } \\
\text { LI. }\end{array}$ & .0200118 & .0045892 & 4.36 & 0.000 & .0110172 & .0290064 \\
\hline $\begin{array}{l}d p r \\
\text { L11. }\end{array}$ & -.0222518 & .0049887 & -4.46 & 0.000 & -.0320296 & -.012474 \\
\hline $\begin{array}{c}\text { diquid } \\
\text { LI. }\end{array}$ & .0002113 & .0012439 & 0.17 & 0.865 & -.0022267 & .0026492 \\
\hline \multicolumn{7}{|l|}{ dgdpn } \\
\hline $\begin{array}{c}\text { dinf1 } \\
\text { LI. }\end{array}$ & -.1058518 & .0178682 & -5.92 & 0.000 & -.1408728 & -.0708307 \\
\hline $\begin{array}{l}\text { dgdpn } \\
\text { LI. }\end{array}$ & .5374339 & .0304507 & 17.65 & 0.000 & .4777515 & .5971163 \\
\hline $\begin{array}{l}\text { dreer } \\
\text { LI. }\end{array}$ & -.0408671 & .0075608 & -5.41 & 0.000 & -.055686 & -.0260481 \\
\hline $\begin{array}{l}d p r \\
\text { L1. }\end{array}$ & -.0367714 & .0025502 & -14.42 & 0.000 & -.0417696 & -.0317732 \\
\hline $\begin{array}{c}\text { diquid } \\
\text { LI. }\end{array}$ & .0067322 & .000338 & 19.92 & 0.000 & .0060697 & .0073946 \\
\hline \multicolumn{7}{|l|}{ dreer } \\
\hline$\underset{\text { dinfl }}{\operatorname{di} .}$ & -.5655512 & .0884556 & -6.39 & 0.000 & -.738921 & -.3921813 \\
\hline $\begin{array}{l}\text { dgdpn } \\
\text { L1. }\end{array}$ & -.7790999 & .0854686 & -9.12 & 0.000 & -.9466153 & -.6115846 \\
\hline $\begin{array}{l}\text { dreer } \\
\text { L1. }\end{array}$ & .1958788 & .0368996 & 5.31 & 0.000 & .1235569 & .2682006 \\
\hline $\begin{array}{l}\mathrm{dpr} \\
\mathrm{L} 1 .\end{array}$ & .1630327 & .020556 & 7.93 & 0.000 & .1227436 & .2033218 \\
\hline $\begin{array}{l}\text { difiquid } \\
\text { LI. }\end{array}$ & -.0036644 & .0085759 & -0.43 & 0.669 & -.0204729 & .0131441 \\
\hline \multicolumn{7}{|l|}{$\overrightarrow{d p r}$} \\
\hline $\begin{array}{c}\operatorname{dinf1} \\
\text { L1. }\end{array}$ & 1.709191 & .0835075 & 20.47 & 0.000 & 1.545519 & 1.872863 \\
\hline $\begin{array}{l}\text { dgdpn } \\
\text { L1. }\end{array}$ & .3579118 & .0588518 & 6.08 & 0.000 & .2425644 & .4732592 \\
\hline $\begin{array}{l}\text { dreer } \\
\text { L1. }\end{array}$ & -.0240035 & .0172309 & -1.39 & 0.164 & -.05777555 & .0097685 \\
\hline $\begin{array}{l}\text { dpr } \\
\text { L1. }\end{array}$ & -.4170778 & .0312059 & -13.37 & 0.000 & -.4782403 & -.3559154 \\
\hline $\begin{array}{c}\text { difuid } \\
\text { LI. }\end{array}$ & .0013713 & .0089886 & 0.15 & 0.879 & -.0162461 & .0189886 \\
\hline \multicolumn{7}{|l|}{ 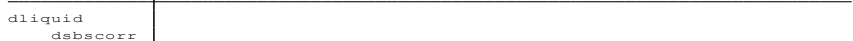 } \\
\hline $\begin{array}{c}\operatorname{dinf1} \\
\operatorname{Li1} .\end{array}$ & -.1767087 & .0344611 & -5.13 & 0.000 & -.2442512 & -.1091662 \\
\hline $\begin{array}{l}\text { dgdpn } \\
\text { LI. }\end{array}$ & .3788007 & .0440009 & 8.61 & 0.000 & .2925605 & .4650409 \\
\hline $\begin{array}{l}\text { dreer } \\
\text { I1. }\end{array}$ & -.1198479 & .0113885 & -10.52 & 0.000 & -.1421689 & -.097527 \\
\hline $\begin{array}{l}\mathrm{dpr} \\
\mathrm{L} 1 .\end{array}$ & .0268801 & .0054117 & 4.97 & 0.000 & .0162733 & .0374869 \\
\hline dliquid & .0014788 & .0038314 & 0.39 & 0.700 & -.0060305 & .0089882 \\
\hline
\end{tabular}

